11.Solovova, E.N. Metodika obuchenia inostrannym iazykam: bazovyi kurs leksi: posobie dlä studentov ped. vuzov i uchitelei: 3-e izd. / E.N. Solovova. - M.: Prosveşenie, 2002. - 239 s. - kniga

12.Küzmina, L.G. Kriterii osenki urovnä sformirovannosti umeni pismennoi inoiazychnoi rechi//Opyt bilingvälnogo obrazovania sredstvami rodnogo i inostrannogo iazykov v Rosii - M.: «Evroşkola», Chäst 2, 1999. - S. 56-58 . - kniga

МРНТИ 16.21.21

https://doi.org/10.51889/2020-2.1728-7804.98

\author{
Askarova S., ${ }^{1}$ Tursynbayeva K., ${ }^{2}$ Chakibayeva A. ${ }^{3}$ \\ ${ }^{1,2,3}$ Kazakh National Women's Teacher Training University, \\ Almaty, Kazakhstan
}

\title{
COMPETENCE-BASED APPROACH IN THE FORMATION OF INTERCULTURAL-COMMUNICATIVE COMPETENCE IN FOREIGN LANGUAGE TEACHING
}

\begin{abstract}
The main aim of learning a foreign language is the development of students foreign language communicative competence which will allow them to integrate as much as possible into the international professional community. This is an important condition for the social adaptation of students to modern life. In the context of the transition from a knowledge-based approach to teaching to a competency-based approach, a change in value orientations, the teacher needs new methods and technologies that allow the teacher to identify the student's knowledge, update it, add what is missing, structure the training material, and teach not only to remember and reproduce, but put them into practice. Methods that organize learning through desire, stimulate students' learning and natural curiosity, motivate interest in the independent acquisition of knowledge. The article deals with the role and importance of applying a new "competencebased approach" in the formation and developing students' intercultural and communicative competence in teaching foreign language. The authors give explanations to such concepts as "competence" and "competency", as well as "competence approach".

Keywords: competence-based approach, competence, modernization, competency, FLT, interculturalcommunicative competence

$$
\begin{gathered}
\text { Аскарова С., }{ }^{1} \text { Турсынбаева К., }{ }^{2} \text { Чакибаева А. } \\
{ }^{3,2,3} \text { Қазақ Ұлттық Қыздар Педагогикальқ Университеті, } \\
\text { Алматы, Қазақстан }
\end{gathered}
$$

\section{ШЕТЕЛ ТІЛІН ОҚЫТУДА МӘДЕНИЕТАРАЛЫҚ ҚАТЫСЫМ КҰЗІРЕТТІЛІГІН ҚАЛЫПТАСТЫРУДАҒЫ БІЛІКТІЛІК АМАЛЫ}

Ан̧датпа

Шетел тілін оқытудың негізгі мақсаты - студенттердің халықаралық кәсіби қоғамдастыққа кірігуіне мүмкіндік беретін шетел тіліндегі коммуникативті құзіреттілігін дамыту. Бұл студенттердің қазіргі өмірге әлеуметтік бейімделуінің маңызды шарты болуда. Білімге негізделген тәсілден оқытуға құзіреттілікке, құндылық бағдарларының өзгеруіне көшу жағдайында мұғалімге оқушының білімін анықтауға, оны жаңартуға, жетілдіруге, оку материалының құрылымын құруға, есте сақтауға және көбейтуге ғана емес, жаңа әдіс-тәсілдер мен технологияларды тәжірибеге енгізуді қажет етеді. Окуды қалау арқылы ұйымдастыратын әдістер студенттердің оқуға деген ынтасын арттырады, олардың табиғи қызығушылығын оятады және білімді өз бетімен алуға қызығушылықты оятады. Мақалада шетел тілін оқытудағы студенттердің мәдениетаралық және коммуникативтік құзіреттілігін қалыптастыру мен дамытуда жаңа «құзіреттілікке негізделген тәсіл» қолданудың рөлі мен маңызы талқыланады. «Құзіреттілік» және «құзірет» сияқты ұғымдарды, сондай-ақ «құзіреттілікке негізделген тәсілдер» түсіндіріледі.
\end{abstract}


Түйін сөздер: құзіреттілік, құзіреттілік көзқарасы, жаңғырту, шеттілдік білім беру, мәдениетаралық- коммуникативті құзіреттілік

\author{
Аскарова С., ${ }^{1}$ Турсынбаева К., ${ }^{2}$ Чакибаева А. ${ }^{3}$ \\ ${ }_{1,2,3}$ Казахский Национальный Женский Педагогический Университет, \\ 2. Алматы, Казахстан
}

\title{
КОМПЕТЕНТНОСТНЫЙ ПОДХОД В ФОРМИРОВАНИИ МЕЖКУЛЬТУРНО-КОММУНИКАТИВНОЙ КОМПЕТЕНТНОСТИ В ОБУЧЕНИИ ИНОСТРАННОМУ ЯЗЫКУ
}

\begin{abstract}
Аннотация
Основная цель изучения иностранного языка - развитие коммуникативной компетенции студентов по иностранному языку, которая позволит им максимально интегрироваться в международное профессиональное сообщество. Это важное условие социальной адаптации студентов к современной жизни. В условиях перехода от знаниевой подхода в обучении к компетентностному, смены ценностных ориентаций учителю необходимы новые методы и технологии позволяющие выявить имеющиеся у ученика знания, актуализировать их, добавлять то, чего не хватает, структурировать учебный материал, учить не просто запоминать и воспроизводить, а применять их на практике. Методы, которые организуют обучение через желание, активизируют обучение учащихся, стимулируют их природную любознательность, мотивируют интерес к самостоятельному приобретению знаний. В статье обсуждается роль и значение применения нового «компетентностного подхода» в формировании и развитии межкультурной и коммуникативной компетентности студентов в обучении иностранному языку. Дается объяснения таким понятиям, как «компетентность» и «компетенция», а также «компетентностный подход».
\end{abstract}

Ключевые слова: компетентностный подход, компетентность, модернизация, иноязычное образование, межкультурно-коммуникативная компетентность

Introduction. Changing in the socio-political context, the development of international contacts in all areas, consolidation of contacts and international integration has led to an increase in the role and importance of skills and abilities of genuine foreign language communication.

Rapid socio-economic progress dictates high demands on the quality of teaching a foreign language in educational institutions, as every new generation of students must rise to a higher level of foreign language proficiency. The change in the socio-cultural context of a foreign language, the new requests of students regarding the level of proficiency of the language, necessitate a qualitative change in the preparation and development of the necessary competencies.

Additionally, consistent changes in the current education (direction, purpose, content) require changes in the previous educational paradigm, focusing on new education in "free human development", creative initiatives, autonomy, competitiveness, and mobility of future professionals. (V.I.Baidenko, G.B.Kornetov, A.N.Novikov, L.G.Semushina, Y.G.Tatur, and others) [1,53].

In connection with the modernization of education, one of the most important tasks facing educational institutions is the formation of key competencies, especially the issue of the competence-based approach in education.

Orientation to the global educational system, membership in the European educational community is a source of new challenges for Kazakhstani scholars in the direction of theoretically reversing the educational outcomes. But, fortunately, these difficulties are successfully solved in all state-run educational institutions.

As one of those decisions, the Concept of Education Development in the Republic of Kazakhstan until 2015 indicated the need to substitute from knowledge-based to competence-based, or result-oriented education content. Therefore, as one of the reform areas of our country is considered a transition from a traditional knowledge-based approach to the development of competence-based approach in the modern higher education system.

The term "competence" (kompetencya) derives from the Latin phrase 'compete', which means that it is appropriate to suit. In general terms, it expresses the relevance of the requirements, established criteria and standards in defined areas and the definition of a defined type of task, which has the potential to be effective, 
with the result that it is possible to assume the result and to assume the situationality $[2,20-26]$. The first term "competence" appeared in the 60s. in XX century in the United States of America, in the framework of training, which aimed at the preparation of competent and competitive professionals.

Methodology. Today it is impossible to achieve the goal, to solve the tasks of teaching schoolchildren a foreign language without creating the conditions for self-appropriation, acquisition and understanding of their knowledge. The task of a modern teacher is not to present knowledge to schoolchildren, but more practical and down to earth, to create motivation and form a set of skills to teach oneself. The purpose of a foreign language as a subject area of schooling is to build communicative competence, that is, the ability and willingness to carry out direct foreign communication. The cooperation of the teacher and the student implies the ability of the teacher to dose and direct the independence provided to the student, which leads to the goalsetting of the autonomy of his cognitive activity as the basis of personal formation and development. The learning process is carried out in conditions of constant active interaction of all students. The student and teacher are equal subjects of instruction. The dominance of any participant in the process is excluded. This teaches a humane, democratic approach to the model. It is very important to distinguish two concepts: competence (kompetentnost) and competency (kompetencya). The "competence" has been identified as an individual category, and "competency" has faded into the curriculum and has been "autonomy" of competencies.

So if "competency"(kompetencya) is the ability and readiness to perform certain tasks, "competence" (kompetentnost) means a human resource (knowledge, skills, ability) to perform a particular task, that is to say he is a competent person by acquiring and acquiring this fund [3,89-117].

And what is meant by a competence approach?

The competence-based approach in education is understood as a method of instruction aimed at developing the ability of students to solve a certain class of professional tasks in accordance with the requirements for personal professional qualities: the ability to search, analyze, select and process information received, transmit the necessary information; possession of skills of interaction with surrounding people, ability to work in a group; possession of mechanisms for planning, analyzing, self-evaluating one's own activities in unusual situations or in conditions of uncertainty; possession of methods and techniques for solving the problems (Mil'rud, R.P., 2004). Competence-based approach makes certain requirements for students and the level of their possession of a foreign language. In this regard, the basic and advanced competencies of students are distinguished. At the basic level, language proficiency is assumed as a means of communication (a certain vocabulary, mastery of basic grammatical structures, knowledge of the laws governing the functioning of the language, familiarity with the cultural environment, etc.). Advanced level suggests that students will use a foreign language to solve practical problems, for example, to find the necessary information on the profile of their specialty. This level has an interdisciplinary nature and is evaluated according to the achieved result, and not only on the correct use of certain grammatical constructions and active vocabulary. The "competence-based education" that is relevant in the modern world defines the quality of education as a final result and the formation of "system of competencies".

According to an academician S.S. Kunanbayeva's work, international development of competence-based approach corresponds to the following characteristics (UNESCO information):

- competence-based approach is formulated as a modern necessity;

- a qualitative and effective indicator is defined by the competence group that should be integrated into the educational system;

- introduction and formulation of "key competencies" (European Council, 1996);

- formation of "core competencies" is included in the strategy of general education development of the states ("Concept of content updating up to 2010" Kazakhstan).

She also main defined features of "Competent education":

- the ability to orientate education to individuals and to base training courses according to the individual's interest;

- characteristic of developmental and age-specific education;

- the ability to independently solve important issues for social and individual problems;

- formation of searching abilities, creativity and creative thinking in solving problems;

- to take into account the individual's personality orientation, to take into account the peculiarities of each person, creative self-development etc. (Kunanbayeva S.S., 2010, pp. 91-93)

Results. Researchers of the competency-based approach to learning offer several classifications of key competencies. According to one of them, the key educational competencies are: 1. Value - semantic. 
2.General cultural.3.Educational - cognitive. 4.Information. 5. Communicative. 6. Social - labor. 7. Personal improvement.

This classification turned out to be the most consistent with the requirements of the competency-based approach, as it was compiled on the basis of the main goals of general education, the structural presentation of social and personal experience, as well as the main activities of the student.

Each of the competences includes a large complex of knowledge, skills, abilities and values. Let us consider this classification in more detail.

1. The value-semantic competence provides a mechanism for self-determination of the student in situations of educational and other activities. It demonstrates what its value orientations are, whether it is able to understand its role and purpose in the world, whether it can choose the settings for its decisions and actions, whether the learner is responsible for choosing the solution. Pupils master this competence, participating in moral conversations, in situations of moral choice of actions.

2. General cultural competence allows students to join the dialogue of cultures, to clarify the cultural foundations of family, social, social phenomena and traditions, the role of science and religion in human life. Simultaneously, this competence shows how much the student is competent in the domestic and culturalleisure sphere (for example, when organizing leisure time).

In terms of studying foreign languages, we are talking about the formation of socio-cultural competence, which is considered:

-as a willingness and ability to find common and specific in the models of development of the studied and native languages;

-to find, compare and generalize cultural information received from different sources and in different languages;

-build speech interaction in accordance with the norms adopted in a particular culture, taking into account the speech specifics.

3. Educational and cognitive competence includes elements of logical, methodological, educational activity, correlated with the real cognizable objects. These include knowledge and skills in organizing goalsetting, planning, analysis, reflection, self-assessment of educational and cognitive activities. For example, students are invited to check their own work (grammar test, composition), already verified by the teacher, but without corrected errors.

4. Information competence provides the skills of the student's activities in relation to information contained in educational subjects and educational fields, as well as in the surrounding world. It is the information competence in the modern world that is the key to successful implementation in various spheres of communication, including professional ones.

5. Communicative competence includes knowledge of languages, ways to interact with surrounding and remote people and events, skills of working in a group, possession of various social roles in the team. Children master this competence in role-playing games, when writing questionnaires and letters.

6. Socio-labor competence is closely related to communicative competence. Social and labor competence directs the ability to own various social roles in the sphere of civil-social and social-labor activity. The main way is role play, during which students not only practice using language skills, but also prepare themselves for future social roles.

7. The competence of personal self-improvement is aimed at mastering the ways of physical, spiritual and intellectual self-development, emotional self-regulation and self-support. In this formation the teacher, his style of communication with people, his spiritual values and priorities play a big role [4, 54-61].

It is these key competencies that make it possible to form a student as a subject of educational activity and education of his personality.

Competence-based approach in FLE requires a creative approach to the organization and construction of the learning process, creating the conditions for the formation and development of practical skills and skills of owning a foreign language speech. Therefore, it is necessary to strive to create such conditions in class when the students learn the language material in a natural way, in the process of communicating the teacher with students among themselves in the life situations we modeled in various ways.

O. E. Lebedev confirms that, "Competence-based approach is a set of general educational goals, the content of education, and an assessment of the educational process and outcomes." Such laws include:

- The essence of education in this way is to solve the problems of students in different life situations, using social practice accumulated in their practice; 
- The content of education is didactically adapted to address cognitive, world-wide, political and other problems using social experience;

- The essence of the educational process is to create conditions for the formation of students' experience, which can independently solve communicative, organizational, moral and other problems;

- Assessment of educational outcomes is based on the analysis of the degree of knowledge and competencies acquired by the trainees at a given stage of study $[5,24]$.

Competencies aren't often formed through theoretical knowledge acquisition, but through natural practice. Therefore, the importance of modern teaching technologies, types and ways of active learning (business games, case study, debates, project preparation), information and communication technologies are increasing in their importance and usage.

As a result of the formation of competence, the product should be measured and evaluated. Here we can consider "Foreign Language", in other words, "English" as competent, as the basis of its content lies in practicality and experience. The discipline "Foreign Language" has a great potential for formation of the main competencies. As key competencies in teaching foreign languages, we are committed to forming " communicative", "intercultural" and "intercultural communicative competence".

It is important to note that the introduction of a competence-based approach to the system of higher professional education in Kazakhstan was preceded by the development of a set of innovations to the organization of education in foreign were presented in the works of S. S. Kunanbayeva [6]: the subject area "foreign language" has been extended to the level of "foreign language education"; a "cognitivelinguocultural" methodology for foreign-language education is proposed, which assumes the formation of intercultural and communicative competence through the study of language and culture and the teaching of language through a "sieve" of two cultures: native and foreign-language, represented by a set of methodological principles (cognitive, conceptual, communicative, sociocultural, linguocultural, personalcentered, developing-reflective). Competence modeling of professional foreign language education was also developed.

Discussion. As a structural result of the qualitative analysis of competence-based approach, the intercultural and intercultural professional competence is got its importance. S.S. Kunanbayeva defines the competence of intercultural dialogue as "a system of integrated specialties formed by the means of foreign language, allowing students and scientific, international workers to effectively carry out their professional activities in a foreign language." The integration of the components of this system is also actively implemented in the process of self-improvement (self-improvement) if implemented in the process of professional development (Kunanbaeva S.S.,2014).

The findings of the present study show us, as the main objective and result of language institutions is to form "intercultural communicative competence" of students, it would be most advantageous and rational to use a new "competence-based approach", that has already taken merited place in new paradigm of FLE allows to achieve this goal and success. As the competence-based approach focuses not only on the final outcome, it also successfully carries out the basic ideas and important functions in the system of foreign language education, while maintaining the capabilities of the other necessary educational (action, personal, oriented, personal-acting, acmeological, contextual, linguocultural) approaches. But also teacher must be enough qualified and well-prepared to use this approach in the maximum level, such as we can consider competence-based approach as a key to success in FLE.

Conclusion. In summing up the above, it is noteworthy that the competent approach - as the pedagogical theory of modern foreign education. Because of the quality of the learning outcomes, the improvement is provided by this approach. To do so, we need to distinguish between key competencies based on the content of knowledge, skills, abilities, creativity, ways of doing things, emotional and value relationships, and we need to form them in the future specialists and teachers. The competence- based approach is considered to be the most unique kind of all the approaches that have been used before since it favors the formation and development of the required and necessary skills and competence not only in theoretical studies, for example succeeding only in studying linguistic speech aspects of the language, but also contributes for the developing the personal qualities of learners, their mobility, readiness to the future profession, to solutions of various problems and situations, to make decisions independently and all this on the basis of foreign language communication. The basis of teaching a foreign language to a greater extent is not subject competencies (although they are reflected in state standards), but key competencies, as more universal. They provide the opportunity for the formation of the student as a subject of educational activity and the education of his personality. 
References:

1. Kunanbaeva S. S. (2014). Kompetentnostnoe modelirovanie profesionälnogo inoiazychnogo obrazovania. [Competent modeling of professional foreign language education.]- Almaty, s. 53

2. Milrud, R. P. (2004). Kompetentnöst v izuchenii iazyka // Inostrannyi iazyk v şkole.,[ Competence in the study of language // Foreign language at school.] - №7. - (s. 20-26)

3. Kunanbaeva S. S. (2014). Kompetentnostnoe modelirovanie profesionälnogo inoiazychnogo obrazovania [Competent modeling of professional foreign language education ] - s. 89-117.

4. Hutorskoi A. V. (2003). Klüchevye kompetensii kak komponent lichnostno orientirovannoi paradigmy obrazovania // Obşestvennoe obrazovanie. [Key Competencies as a Component of the Personally Oriented Education Paradigm // Public Education] № 2. (str. 54-61).

5. Lebedev O. E. (2004). Kompetentnostnyi podhod v obrazovanii // Şkölnye tehnologii.[Competence approach in education // School technology] - № 5.

МРНТИ 14.35.07.

https://doi.org/10.51889/2020-2.1728-7804.99

\author{
Ayazbayeva A., ${ }^{1}$ Aldaberdy A., ${ }^{2}$ Kabdenova A. ${ }^{3}$ \\ ${ }^{1,2,3}$ L.N.Gumilev Eurasian National University, \\ Nur-Sultan, Kazakhstan
}

\title{
EARLY LEARNING OF ENGLISH WITH FAIRY TALES, SONGS
}

\section{Abstract}

This article is about early education of English to children, with the help of fairy tales and songs. Fairy tale is best to the age children's characteristics of learning a foreign language, helps to develop their memory, thinking, attention and imagination. The article describes the experience and conclusions of various psychologists and teachers, examines the various positions of linguists. In this article various fairy tales and songs are offered, that are well received by children at an early stage. It is said, that this method is not fully studied, not enough evidence for making final or definite solution, but still there are good results in improvement of learning a foreign language.

Keyword: fairy tales, songs, lifelong education, the English language, early education, trilingualism

$$
\begin{gathered}
\text { Аязбаева Ә., }{ }^{1} \text { Алдабердіқызы А., }{ }^{2} \text { Кабденова А. }{ }^{3} \\
{ }_{1,2,3} \text { Л .Н.Гумилев атындавыЕуразия Ұлттық Университеті, } \\
\text { Нур-Султан, Казахстан }
\end{gathered}
$$

\section{КІШІ ЖАСТАҒЫ БАЛАЛРҒА АҒЫЛШЫН ТІЛІН ЕРТЕГІ МЕН ӘН АРҚЫЛЫ ҮЙРЕТУ}

\section{Аңุдатпа}

Бұл мақалада кіші жастағы балаларға ертегілердің көмегімен ағылшын тілін оқыту әдісі қарастырылады. Шет тілін оқыту кезінде ертегіні қолдану балалардың жас ерекшеліктеріне сәйкес келеді, ол баланың жадысын, ойлауын, назарын және қиялын дамытуға көмектеседі. Мақалада әр түрлі психолог-педагогтердің тәжірибесі мен қорытындылары ұсынылған, тіл .үйренушілердің түрлі ұстанымдары қарастырылған. Кіші жастағы балалар жақсы қабылдайтын әр түрлі ертегілер, әндер ұсынылған. Мақалада оқытудың бұл әдісі толық зерттелмеген, бірақ бала кезінен шет тілін үйренетін балалар арасында оң нәтижелер бар. Сондай-ақ, шет тіліндегі сөздер ертегі оку және ән үйрену арқылы ғана емес, сонымен қатар балалар түрлі-түсті жарнаманы, мультфильмдерді және т. б. көріп, естігенде есте қалуы мүмкін.

Түйін сөздер: ертегілер, әндер, шет тілі, үздіксіз білім беру, үштілдік, ерте оқыту 